\title{
Change in diversity and abundance of nematode destroying fungi in land use under irrigation in selected small scale irrigation schemes in Kenya
}

\author{
Wachira P. M. ${ }^{1,}$, Kimenju J. W. ${ }^{2}$, Otipa M. ${ }^{3}$ \\ ${ }^{1}$ School of Biological Sciences, University of Nairobi, Nairobi, Kenya \\ ${ }^{2}$ Department of Plant Science and Crop Protection, University of Nairobi, Nairobi, Kenya \\ ${ }^{3}$ Kenya Agricultural and Livestock Research Organization, Nairobi, Kenya \\ Email address: \\ pwachira@uonbi.ac.ke (Wachira P. M.),wkimenju@yahoo.com (Kimenju J. W.), otipamj@gmail.com (Otipa M.)
}

\section{To cite this article:}

Wachira P. M., Kimenju J. W., Otipa M.. Change in Diversity and Abundance of Nematode Destroying Fungi in Land Use under Irrigation in Selected Small Scale Irrigation Schemes in Kenya. Agriculture, Forestry and Fisheries. Vol. 4, No. 1, 2015, pp. 7-13.

doi: $10.11648 /$ j.aff.20150401.12

\begin{abstract}
Intensity of land cultivation is usually associated with increase in crop production and loss of soil biodiversity or its function. This study was conducted to determine the effect of intensity of land use under irrigation on the occurrence, abundance and diversity of nematode destroying fungi in selected small scale irrigation systems in Kenya. The study was conducted in four spatially separated irrigation schemes namely Kabaa and Kauti in Machakos and Kathiga Gacheru and Mbogooni) in Embu. The study areas were stratified according to land use, which included the irrigated land, rain-fed cultivated land and undisturbed land under fallow. The period of cultivation also differed with the oldest cultivated irrigation system, having been opened in 1960, while the youngest having been opened in 2011. Soil samples were collected from the study site for isolation of nematode destroying fungi. The soil sprinkle and culture technique was used to isolate soil nematode destroying fungi from the soil samples. A total of 216 fungal isolates were identified as nematode destroying fungi belonging to six genera namely Acrostalagmus, Arthrobotrys, Haptoglossa, Harposporium and Monacrosporium. All the isolates were identified resultingto nine species. $49.5 \%$ of all the fungi were isolated from irrigated land while, the rain-fed and the undisturbed land uses accounted for 29.7 and $20.8 \%$ of the isolates, respectively. The oldest irrigation systems had the least diversity (0.110) of nematode destroying fungi compared to the youngest which had a diversity index of 1.311 .The species Arthrobotrys oligospora was the most frequently isolated fungus followed by Monacrosporium cionapagum with occurrence frequencies of 57 and 53\%, respectively. The least frequently isolated species was Nematoctonus leiospora with an occurrence frequency of $2.3 \%$. Of the total identified species, only Nematoctonus leiosporus and Arthrobotrys dactyloides were not affected by the irrigation activities.). From the study, it is evident that land use intensity under irrigation system and the duration of cultivation impacts on occurrence and diversity of nematode destroying fungi in the soil.
\end{abstract}

Keywords: Arthrobotrys oligospora, Bio -Control, Monacrosporium cionopagum, Plant Parasitic Nematodes, Soil Biodiversity

\section{Introduction}

Agriculture is the main occupation and source of income for the majority of Kenya population accounting for one third of the Gross Domestic Product and employs more than two thirds of the country's labor force (Republic of Kenya, 2005). With three quarters of the country's land being uncultivable, coupled with rapid increase in population, sustainability of food production becomes a key area of focus. In an effort to increase food production for the increasing population in
Kenya, continuous fragmentation of arable land and illegal forest clearance have only compounded the problem. This has resulted in intensive agricultural production through irrigation systems in many parts of Kenya. These agricultural production systems are characterized by a low fallow ratio and high use of pesticides and chemical fertilizers relative to land area with the aim of increasing farmer's income and reducing poverty ( $\mathrm{Wu}$ and $\mathrm{Li}, 2013)$. The main characteristics 
of land under irrigation include frequent watering and regular turning of the soil, addition of inorganic fertilizers and pesticides and continuous cultivation of the land all geared towards increased crop production. The examples of crops grown in these schemes are water-intensive and high-value crops such as French bean, green maize/corn, snow peas, onion, tomato, spinach, cabbage, kale, and watermelon among other horticultural crops. Products with these schemes are used to meet subsistence demands as well as domestic and export markets (Neubert, 2007). Irrigation therefore plays an important role in national economic development by increasing crop diversity and yield. Concomitantly there is a raise in food security, an increased income and empowerment of the people in this sector. This leads to improve quality of life to smallholder farmers, government scheme households and persons employed in commercial farms.

Due to this, there is persistent pressure on the soils under irrigated production systems to produce more and more harvests. This pressure has resulted in disruption of the soil ecological balance ( $\mathrm{Li}$ et al., 2013). It has been reported that addition of inorganic fertilizer into the soil has led to increased soil pests and diseases and reduction of beneficial microorganism (Singh, 2000). In addition, continuous and prolonged cultivation of the soil affects the soil quality by changing the soil structure that has been associated with reduced soil biodiversity (Muya et al., 2009). Other negative effects of intensive cultivation include buildup of pests and diseases (Maina et al, 2009), siltation, low irrigation water use efficiency, high cost of production and declining soil fertility. For example, intensive agriculture has been associated with increase in soil pathogenic fungi especially Fusarium spp. (Luque et al., 2005). Some of the farmer practices in the irrigation schemes such as monoculture, excessive tillage, and pesticide use, disrupt the natural regulatory mechanisms in the soil leading to build up of soil pests (Altieri and Nicholls, 2003).

The major crop pests in irrigation systems are the plant parasitic nematodes (Jones et al., 2011.) They are known to cause mechanical damage and malfunctions of the plant roots leading to alteration of the plant growth and development, resulting in poor growth and reduced yield (Bridge et al., 2005). Damage by nematodes is often associated with retarded growth and chlorosis due to inability of the roots to deliver water and nutrients and thus may be confused with similar symptoms resulting from poor soil conditions and nutrient deficiency. Plant parasitic nematodes are very important pests especially in irrigated systems due to the susceptibility of the crops grown, diversity of the host range and also favorable moisture, which is provided by the regular watering. In particular, the root knot nematodes cause severe yield losses by reducing the quantity and quality of the harvestable products. They have been reported to cause more than a third of the total yield. In addition, they are known to open up avenues in the roots for other pathogens like fungi and bacteria. They have also been recorded as the responsible organisms for the huge crop loss in tomato for smallholder growers in Kenya (Oruko and Ndungu, 2001).In this regard, the management of plant parasitic nematodes in agricultural crops has attracted a lot of attention (Garcia et al., 2004) with chemical nematicides being regular inputs (Akhtar and Malik, 2000). Although chemical nematicides are efficient and fast acting, they are currently being reappraised with respect to the environmental hazards associated with them and unaffordability to many small-scale farmers (Wachira et al., 2009).This has created pressure on farmers to adopt nematode management strategies that are environmentally friendly and affordable. As a result, the crave to biological control of plant parasitic nematodes as a viable practice in modern agriculture and horticulture has increased dramatically (Mashela et al., 2008). This has led to the exploration of the nematodes destroying fungi, which are natural enemies of plant parasitic nematodes as the possible candidates for development. So far more than 160 fungal species that live on nematodes, partially or entirely, have been reported (Elshafieet.al. 2006). The fungi use specialized structures and toxins to capture and destroy nematodes (Luo et al., 2004; Yang et al., 2007).Consequently, this group of fungi has drawn much attention because of their potential as biological control agents of nematodes that are parasitic on plants (Masoomeh et al., 2004; Yan et al., 2005).

The aim of this study was therefore to determine the effect of irrigation soil for agricultural production on the occurrence and diversity of nematode destroying fungi with the ultimate goal of utilizing these fungi in the management of plant parasitic nematodes in the smallholder irrigation schemes in Kenya.

\section{Materials and Methods}

\subsection{Characterization of the Target Irrigation Schemes}

The study was conducted within small scale irrigation schemes in Machakos, Embu, and Meru counties of Kenya: The criteria for selection of the sites were soil type, cultivation period and crops cultivated. The schemes selected for this study were Kauti and Kabaa irrigation schemes in Machakos county, Kathiga-Gacheru in Embu county and Mboogoni in Meru. The schemes were characterized in terms of crops grown, water source and production constraints (Table 1). All the irrigation schemes under study had different crop production constraints with pests and diseases being common in all of them. Other production constraints identified included, siltation, low irrigation water use efficiency, inappropriate management skills, and high cost of production, lack of organized marketing, poor seed quality and declining soil fertility. The two irrigation schemes in Machakos (Kabaa and Kauti-Kathiani) obtained irrigation water from dams while those in Embu and Meru obtained water from the rivers. A wide range of crops is grown in the irrigation schemes with tomato production being common to all of them. Kabaa irrigation scheme was the largest scheme with 240 ha being under irrigation while Kauti-Kathiani was the smallest scheme with only66 ha, being under irrigation. Mboogoni irrigation scheme had 100 ha under irrigation 
while only 80 ha were under irrigation in Kathiga- Gacheru irrigation scheme. Kabaa irrigation scheme would be considered the oldest irrigation scheme among the four schemes, having been established in 1960. The irrigation canal was rehabilitated and the area under irrigation was expanded in 2011. Kathiga- Gacheru irrigation scheme was fully established in 1984. The other two irrigation schemes (Mboogoni and Kauti - Kathiani) were established in 2011.

Table 1. Characteristics of four selected smallholder irrigation schemes selected for a study of nematode destroying fungi in Kenya.

\begin{tabular}{|c|c|c|c|c|c|c|}
\hline Scheme & Location & Acreage & $\begin{array}{l}\text { Year } \\
\text { Established }\end{array}$ & Main crops & $\begin{array}{l}\text { Water } \\
\text { source } \\
\end{array}$ & Main crop production constraint \\
\hline Kabaa, & Machakos & 240 ha, & 1960 & $\begin{array}{l}\text { French bean, tomato, onion, } \\
\text { banana, kale, cabbage and } \\
\text { passion fruit. }\end{array}$ & Dam & $\begin{array}{l}\text { Pests and diseases, siltation, low irrigation } \\
\text { water use efficiency, inadequate management } \\
\text { skills, high cost of production and declining } \\
\text { soil fertility. }\end{array}$ \\
\hline $\begin{array}{l}\text { Kauti- } \\
\text { Kathiani }\end{array}$ & Machakos & 66 ha & 2011 & $\begin{array}{l}\text { French bean, kale, tomato, } \\
\text { maize and coffee }\end{array}$ & Dam & $\begin{array}{l}\text { Pests and diseases, inadequate water supply, } \\
\text { low soil fertility, lack of skilled labourand high } \\
\text { post-harvesting losses }\end{array}$ \\
\hline Mboogoni & Meru South & 100 ha & 2011 & $\begin{array}{l}\text { Banana, tomato, green maize, } \\
\text { watermelon and mango. }\end{array}$ & River & $\begin{array}{l}\text { Pests and diseases, inadequate water, no } \\
\text { organized marketing group and poor seed } \\
\text { germination }\end{array}$ \\
\hline $\begin{array}{l}\text { Kathiga- } \\
\text { Gacheru }\end{array}$ & Mbeere & 80 ha & 1984 & $\begin{array}{l}\text { Pawpaw, tomato, butternut, } \\
\text { watermelon, kale and onion. }\end{array}$ & River & Pests and diseases, poor cropping patterns \\
\hline
\end{tabular}

\subsection{Soil Sampling}

Each of the study area was stratified into three main land uses, the irrigated land, rain-fed cultivated land and the undisturbed/ natural land. The soil sampling method was adopted from Moreira et al, 2008 with some modification. From each land use type, a total of ten farms were randomly identified for soil sampling. From each farm/sampling point, a central position was determined and marked. From the center, four diagonals of six meters long were drawn and the soil sampled at the three and six meter lengths including the center. Soil sampling was done using a soil auger, which was sterilized between sampling points to avoid cross contamination. A total of 120 soil samples were collected for this study. The soil samples were placed in a cool box and transported to the laboratory for isolation of nematode destroying fungi. All the laboratory work was done at the University of Nairobi, Mycology laboratory.

\subsection{Isolation of Nematode Destroying Fungi}

Isolation of the fungi was done using the soil sprinkle technique as described by Jaffee et al., (1996). One gram of soil from each soil sample was transferred to a previously prepared sterile solid potato dextrose agar (PDA) medium in a Petridish and spread evenly. A suspension of approximately 500 juveniles Meladogyne incognita was added as bait in each petri dish and incubated at room temperature. Observations on fungal growth were conducted every week after the third week of incubation for three weeks. Observations on dead nematodes and the mycelia growth in the petridish were conducted under the dissecting microscope and then under a compound microscope at a magnification of $\mathrm{x} 40$. Identification was based on the type and size of conidia, the habit of the conidiophore and the type of nematode destruction structure produced.

\subsection{Data Analysis}

Generalized linear models were fitted to test the effect of land intensity on the occurrence of nematode destroying fungi. Frequency of occurrence, evenness, Renyi profiles and the Shannon diversity index were also calculated (Kindt and Coe, 2005).

\section{Results}

Land use intensification under irrigation has a significant $(\mathrm{P}=0.05)$ effect on the occurrence of nematode destroying fungi. Overall, $49.5 \%$ of all the isolated nematode destroying fungi was obtained from the irrigated land while, 29.7 and $20.8 \%$ were recovered from the rain fed and uncultivated land respectively (Fig. 1). Similar trend of occurrence of nematode destroying fungi was observed in all the irrigation schemes with the irrigated land uses having higher numbers of occurrence of nematode destroying fungi followed by the rain fed land uses and the least being the uncultivated land uses.

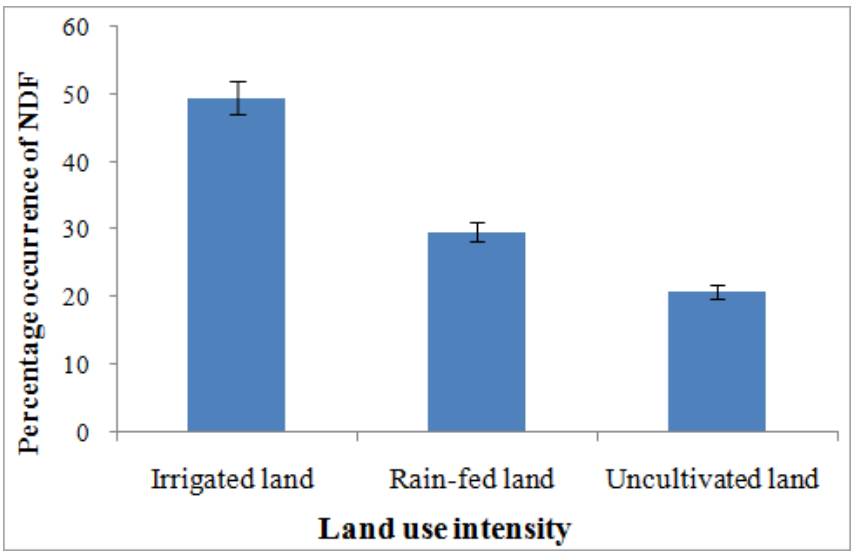

Figure 1. Percentage frequency of occurrence of nematode destroying fungi in land under different levels of disturbance.

From the results, it was evident that the old irrigation systems had the least number of nematode destroying fungi compared to the recently established irrigation systems (Fig 2). Kauti irrigation scheme had the highest percentage record 
(45.8\%) of nematode destroying fungi. Kabaaand Mboogoni had a record of 20.8 while $12.5 \%$ was recorded for Kathiga-

Gacheru.)

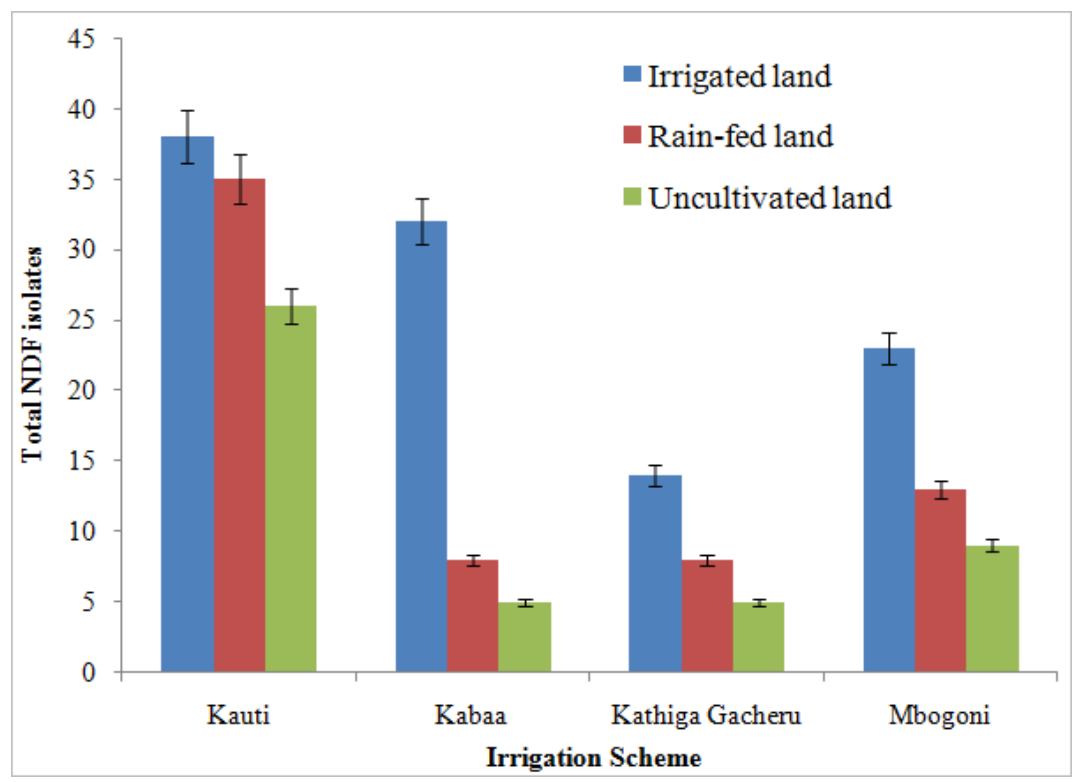

Figure 2. Nematode destroying fungi recorded in irrigation scheme.

The diversity of nematode destroying fungi varied among the irrigation scheme (Table 2). Kauti irrigation scheme was the most diverse with a mean Shannon of 1.311 , followed by Kauti rain fed systems with 1.218 while the third was Kabaa irrigated systems with 1.078. The rest had mean Shannon of less than 1 . The land uses with the least number of nematode destroying fungi were in Kathiga Gacheru irrigation schemes with mean mean richess of 8,5 and 4 in the rain-fed, uncultivated and irrigated lands, respectively.

A total of 216 fungal isolates were positively identified as those of nematode destroying fungi. The fungi were grouped into six genera and nine species. The six genera were, Arthrobotrys, Acrostalagmus, Harposporium, Haptoglossa, Monacrosporium and Nemtoctonus. The genus Arthrobotrys was represented by three species namely, A.dactyloides, A.longispora and A. superba. All the other genera were represented by one species. With the exception of $A$. dactyloides and Nematoctonus leiosporus, all the other species of nematode destroying fungi were significantly affected by land use intensity (Table 2 ).

Arthrobotrys oligospora was the most frequently isolated nematode destroying fungal species with $26.1 \%$ occurrence, which was closely followed by Monacrosporium cionapagum with isolation frequency of $24.5 \%$. The least frequently isolated species were Harposporium aungullilae and Nematoctonus leiosporus with percentage frequencies of 4.2 and $2.3 \%$, respectively (Table 3 )

The species cumulative curve indicated that the 120 samples collected in this study were sufficient to detect all the available nematode destroying fungi in the study site. The curve had already flattened at 80 samples (Figure 3)

Table 2. Richness, Shannon indices and abundance of nematode destroying fungi in various land use systems in selected irrigation schemes in Kenya.

\begin{tabular}{llll}
\hline Irrigation Scheme/land use & Mean richness & Shannon index & Abundance \\
\hline Kathiga Gacheru Irrigated & 0.4 & 0.277 & 4 \\
Kathiga Gacheru rain-fed & 0.8 & 0.139 & 8 \\
Kathiga Gacheruuncultivated & 0.5 & 0.110 & 5 \\
Kauti- Kathiani Irrigated & 3.8 & 1.311 & 38 \\
Kauti- Kathiani rain-fed & 3.5 & 1.218 & 35 \\
Kauti- Kathianiuncultivated & 2.6 & 0.855 & 26 \\
Mbogoni Irrigated & 2.3 & 0.717 & 23 \\
Mbogoni rain-fed & 1.3 & 0.277 & 13 \\
Mbogoni uncultivated & 0.9 & 0.139 & 9 \\
Kabaa Irrigated land & 3.2 & 1.078 & 32 \\
Kabaa Rain-fed production & 0.8 & 0.179 & 8 \\
Kabaa uncultivated & 0.5 & 0.139 & 5 \\
\hline
\end{tabular}


Table 3. Effect of land use intensity on occurrence of nematode destroying fungal species in selected irrigation schemes in Kenya.

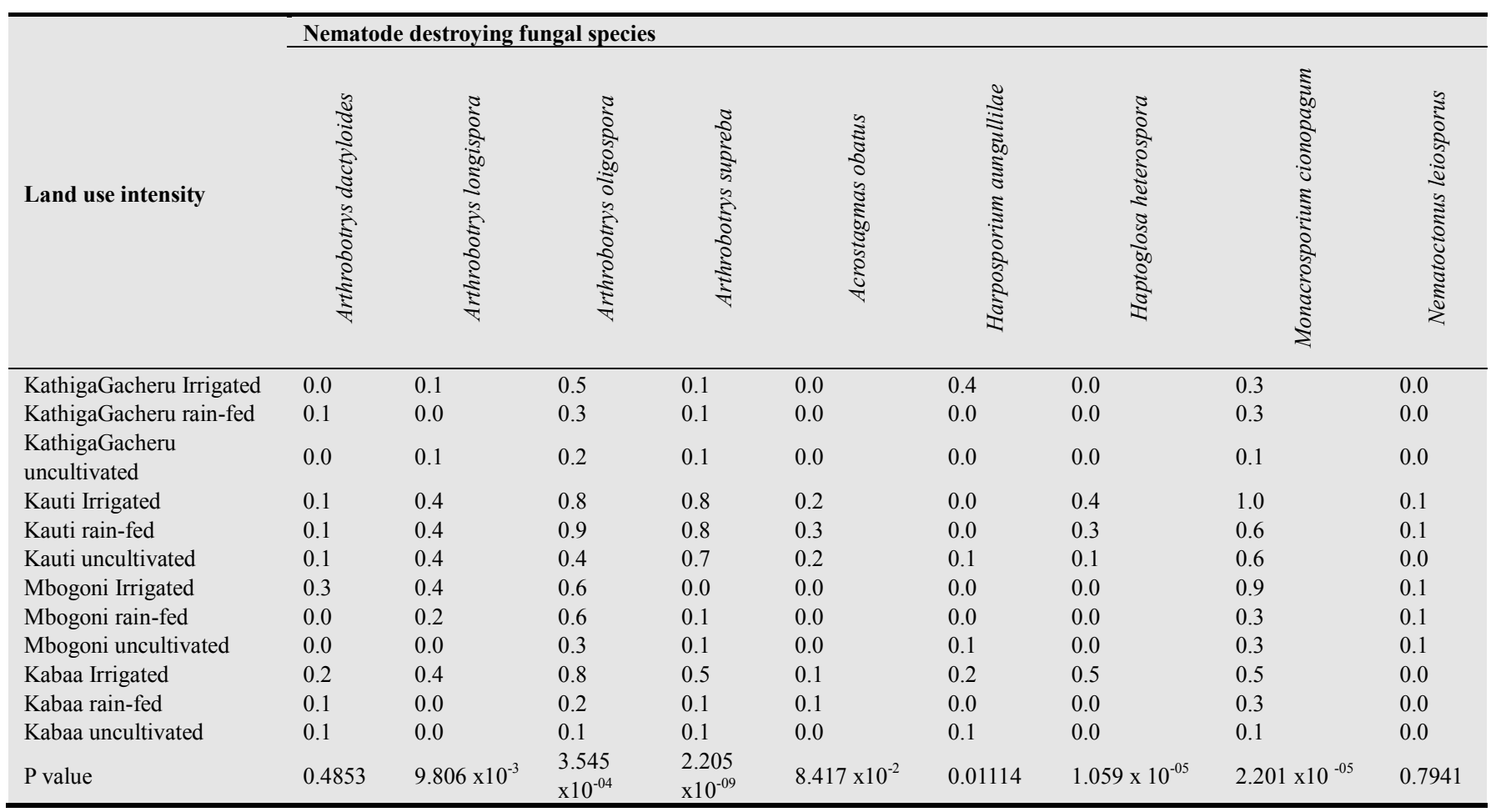

Table 4. Rank, abundance and proportion of nematode destroying fungi isolated from four irrigation schemes in Kenya.

\begin{tabular}{lllll}
\hline Species & Rank & Abundance & Proportion & Accumulative frequency \\
\hline Arthrobotrys oligospora & 1 & 57 & 26.1 & 26.4 \\
Monacrosporium cionapagum & 2 & 53 & 24.5 & 50.9 \\
Arthrobotrys superba & 3 & 35 & 16.2 & 67.1 \\
Arthrobotrys longispora & 4 & 24 & 6.0 & 78.2 \\
Haptoglossa heterospora & 5 & 13 & 5.1 & 84.3 \\
Arthrobotrys dactyloides & 6 & 9 & 4.2 & 89.4 \\
Acrostalagmus obatus & 7 & 9 & 4.2 & 93.5 \\
Harposporium aungullilae & 8 & 5 & 2.3 & 97.7 \\
Nematoctonus leiosporus & 9 & & 100.0 \\
\hline
\end{tabular}

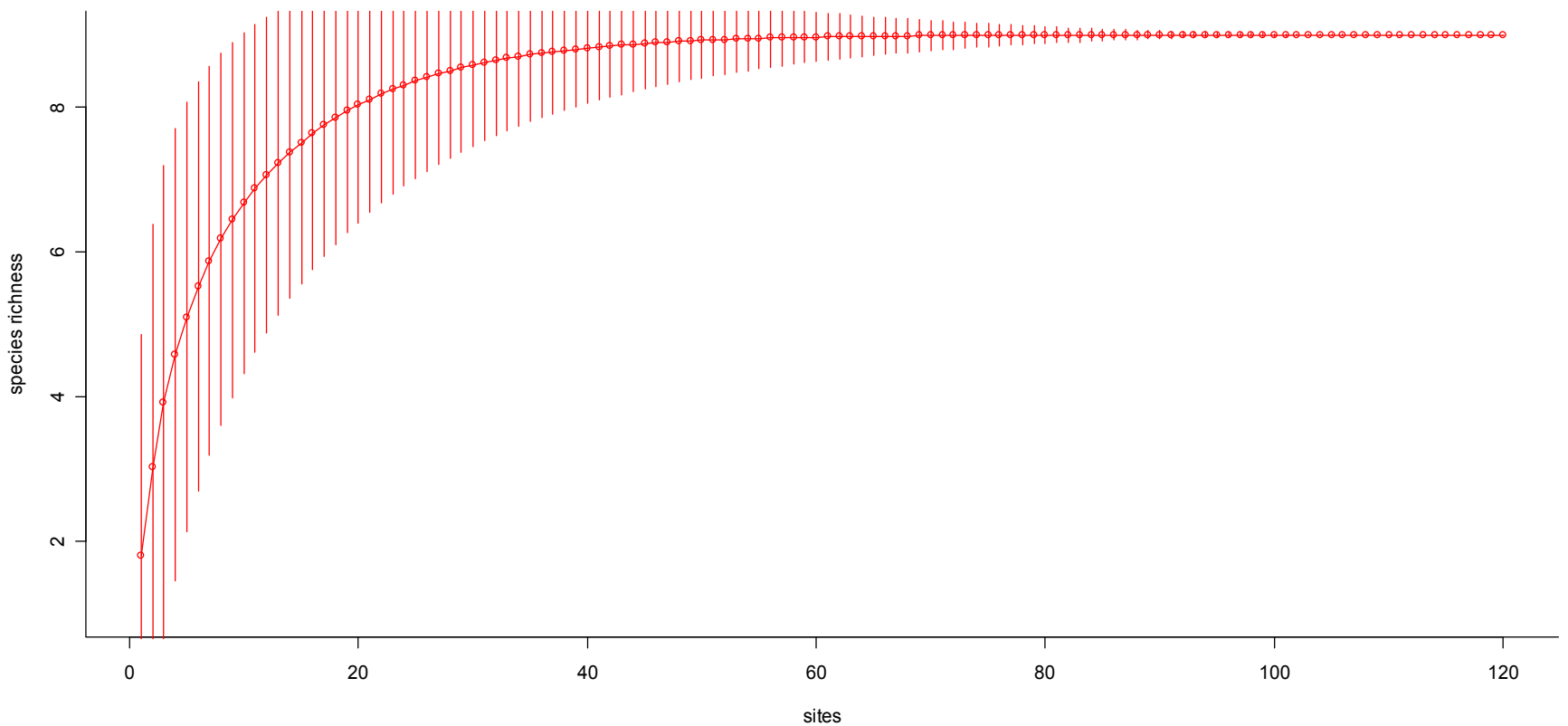

Figure 3. Species cumulative curve of nematode destroying fungi in the selected irrigation systems in Kenya. 


\section{Discussion}

Agricultural intensification under irrigation is one of the key practices for increased crop production world allover. In Kenya the total area under irrigation is about 80,000 hectares with public and private small-scale irrigation being less than $50,000 \mathrm{ha}$. This is still very small compared to the estimated potential of more than 300,000 ha, with water availability and quantity being one of the challenges. From this study, dams and rivers were identified as the main sources of irrigation water although other sources like wells, lakes and seas have been reported in other countries. From the study area, the farms were characterized by heavy usage of pesticides, and chemical fertilizers in order to increase productivity. It was noted that the irrigation systems were inserting great pressure on the environment by degradation and depletion of the natural resource, like soil, water and natural plants as identified in the production constrains from the four irrigation schemes, similar to those reported by Burney et al., 2010 and Moeskops, et al., 2010.

The main production constrains identified in the four studied irrigation schemes were poor soil fertility and pests and disease. This was thought to arise from reduction of soil organic matter through removal of organic materials and soil erosion. In all the four irrigation schemes, removal of crop materials is highly practiced in order to reduce disease inoculum from the soil. However, this practice has been associated with reduced soil fertility (Su et al., 2006; Lou et al., 2011). It has been proposed that one of the strategies to improve soil fertility is to manage soil organic matter, which, other than maintaining soil fertility, it is important in sustaining the productivity of agro ecosystems (Lou et al., 2011).

Despite the fact that application of chemical fertilizers and chemical pesticides has improved crop production, this has fundamentally changed farming practices world over leading to loss of mixed agriculture with farms becoming increasingly specialized. Arable farming (field crops) and traditional crop rotation has been abandoned leading to a population decline of many species living on farmland (Boatman et al., 2007), including the non-target species, e.g. the birds, (Walker, et al, 2008). Pesticides therefore are a major factor affecting biological diversity, along with habitat loss and climate change. Terrestrial and aquatic biodiversity have also declined rapidly due to excessive use of fertilizers, pesticides, tillage and even crop rotation (Tilman et al., 2002; Tilman et al., 2006). Furthermore, microbial biomass has been reported to correlate positively with yield in organic farming compared to conventional farming systems (Tu et al., 2006).

From the current study, soils under irrigation harbored more nematode destroying fungi compared to the rain-fed and the non-cultivated soils. This could be attributed to the frequent tillage of land, which scatters the fungi mycelia in the farm increasing the chances of detection (Wachira et al., 2009). Irrigated land receives frequent tillage compared to the rain fed land use. Irrigated land was characterized with a diversity of crops, which are grown on short cycles increasing microbial host range. On the other hand, the rainfed land use experience high organic matter especially after crop harvest. Although the crop debris is important in promoting microbial activity, the land use is challenged with reduced moisture which is important for microbial activity hence the reduced occurrence of nematode destroying fungi. The undisturbed land use had the least abundance and diversity of nematode destroying fungi in all the irrigation systems probably due to reduced soil moisture and organic matter compared to the other two land uses systems. Microbial communities in undisturbed ecosystems achieve ecological stability and therefore occupy specific niches and are more resilience. This reduces their chances of detection and hence the low records of nematode destroying.

Continuous cultivation of land for a long period lead to reduced detection of nematode destroying fungi. This was evidenced among the four irrigation schemes in this study. This was demonstrated by the fact that Kauti irrigation scheme had the highest number of nematode destroying fungi and was established most recently (year 2011) compared to Kathiga - Gacheru that was established in 1985 and had the least number of nematode destroying fungi. In agreement with this observation, Powlson et al., (2013) reported that prolonged cultivation breaks down the soil structure that negatively affects microbial population. This then could explain the low frequency of detection of nematode destroying fungi in the older irrigation systems. A similar trend was observed between Kabaa and Mboogoni where Kabaa was established in 1960 and only rehabilitated in 2011 while Mboogoni was established in 2011.

It can be concluded that nematode destroying fungi are spread in all land uses and forms part of the soil microbial community and that their occurrence and diversity is influenced by soil management system. It was also clear that prolonged cultivation of soil reduces the diversity of soil microorganism, hence reducing the chances of isolation and detection of the nematode destroying fungi. It is proposed that the high number of nematode destroying fungi could be utilized for the management of soil pests and diseases especially the management of plant parasitic nematodes in the cultivated land.

\section{Acknowledgment}

The authors would like to acknowledge the following institutions for facilitating this study, The Ministry of Agriculture, The African Development Bank, Kenya Agricultural and Livestock Research Organization and the University of Nairobi.

\section{References}

[1] Akhtar, A., and A. Malik, 2000. Roles of organic soil amendments and soil organisms in the biological control of plant parasitic nematodes: a review. Bioresource Technology 74: $35-47$ 
[2] Altieri,M.A and Nicholls, C. I., 2003. Soil fertility management and insect pests: harmonizing soil and plant health in agro ecosystems. Soil and Tillage Research 72: 203211.

[3] Boatman ND, et al, Impacts of agricultural change on farmland biodiversity in the UK, In: Hester RE, and Harrison RM (eds), Biodiversity under threat, RSC Publishing, Cambridge, UK 2007, pp. 1-32.

[4] Burney, J.A., Davis, S.J., Lobell, D.B., 2010. Greenhouse gas mitigation by agricultural intensification. PNAS 107, 1205212057.

[5] Elshafie, A.E., Al-Mueini, R., Al- Bahry, Akindi, A., Mohmoud, I., and Al- Rawahi, S., 2006. Diversity and trapping efficiency of nematophagous fungi from Oman.PhytopathologiaMediterranea.45: 266 - 270.

[6] García-Álvarez, A., Arias, M., M. A. Díez-Rojo and A. Bello, 2004. Effect of agricultural management on soil nematode trophic structure in a Mediterranean cereal system. Applied Soil Ecology 27:197-210

[7] Jones J. et al. (eds.), 2011. Genomics and Molecular Genetics of Plant-Nematode Interactions. Published by Springer Science and Business Media B.V. 2011.Pages 21 - 43.

[8] Kindt R and R. Coe, 2005.Tree diversity analysis. A manual and software for common statistical methods for ecological and biodiversity studies. Nairobi: World Agro-forestry Center (ICRAF).

[9] Li, Man, JunJie Wu, Xiangzheng Deng, 2013. Identifying drivers of land use change in China: A spatial multinomial logit model analysis. Land Economics 89: 632-654.

[10] Lou, Y., Wang, J., Liang, W., 2011. Impacts of 22-year organic and inorganic $\mathrm{N}$ managements on soil organic $\mathrm{C}$ fractions in a maize field, northeast China. Catena. Vol. 87 ( 3) 386-390.

[11] Luo, H., Mo M, Huang X,Li X., and Zhang, K., 2004. Coprinuscomatus: A basidiomycete fungus forms novel spiny structures and infects nematode. Mycologia 96: 1218-1224.

[12] Mashela, P.W., H.A. Shimelis and Mudau F. N., 2008. Comparison of the efficacy of ground wild cucumber fruits, aldicarb and fenamiphos on suppression of Meloidogyne incognita in tomato. Phytopathology 156: 264 -267.

[13] Masoomeh, S.G., Mehdi, R.A., Shahrokh, R.B., Ali, E., Rasoul, Z. and Majid E., 2004. Screening of Soil and Sheep Faecal Samples for Predacious Fungi: Isolation and Characterization of the Nematode-Trapping Fungus Arthrobotrysoligospora. Iranian Biomedical Journal8: 135142.

[14] Moeskopsa, B., Sukristiyonubowob, Buchana, D., Sleutel, S., Herawatyb, L., Husenb, E., Saraswati, R., Setyorini, D., Nevea, S., 2010. Soil microbial communities and activities under intensive organic and conventional vegetable farming in West Java, Indonesia. Applied Soil Ecology 45,112-120.
[15] Moreira, F. M. S.; Huising, E. J.; Bignell, D. E. (2008). A Handbook of Tropical Soil Biology: Sampling and Characterization of Below Ground Biodiversity. Earthscan, UK $218 \mathrm{pp}$.

[16] Oruko, L. and Ndungu, B., 2001. Final social - economic report for the Peri-Urban Vegetable IPM Cluster.CABI/KARI/HRI/NRI/ University of Reading/ IACR Rothamsted Collaborative Project.

[17] Powlson, D.S.; Gregory, P.J.; Whalley, W.R.; Quinton, J.N.; Hopkins, D.W.; Whitmore, A.P.; Hirsch, P.R.; Goulding, K.W.T . 2013. Soil Management In Relation To Sustainable Agriculture and Ecosystem Services. Food Policy36 (1): 572 587.

[18] Republic of Kenya (2005). Economic Survey 2005. Government Printer, Nairobi.

[19] Singh, R.B., 2000. Environmental consequences of agricultural development: a case study from the Green Revolution state of Haryana, India. Agriculture, Ecosystems and Environment 82: 97-103.

[20] Su, Y.Z., Wang, F., Suo, D.R., Zhang, Z.H., Du, M.W., 2006. Long-term effect of fertilizer and manure application on soilcarbon sequestration and soil fertility under the wheat-maize cropping system in northeast China. Nutrient Cycling in Agro ecosystems $75,285-295$.

[21] Tu, C., Ristaino, J.B., Hu. S., 2006. Soil microbial biomass and activity in organic tomato farming systems: Effects of organic inputs and straw mulching. Soil Biology and Biochemistry 38, 247-255.

[22] Wachira,P. M., J.W. Kimenju, S.A. Okothand R. K. Mibey, 2009. Stimulation of nematode -destroying fungi by organic amendments applied in management of plant parasitic nematode. Asian Journal Plant Sciences. Volume 8: (2) 153 159.

[23] Walker et al., 2008. The Predatory Bird Monitoring Scheme: Identifying chemical risks to top predators in Britain, Ambio 37(6): 466-471, 2008)

[24] WuJunJie and Li Man, 2013.Land Use Change and Agricultural Intensification: Key Research Questions and Innovative Modeling Approaches.A Background Paper Submitted to The International Food Policy Research Institute.Final Report, November 2013.

[25] Yan, L.K., Hyde, R., Jeewon, L., CaiD., and Vijaykrishnak, Z., 2005. Phylogenetics and evolution of nematode-trapping fungi (Orbiliales) estimated from nuclear and protein coding genes. Mycologia 97: 1034 -1046.

[26] Yang, Y., Yang E., An Z. and Liu X, 2007:Evolution of nematode-trapping cells of predatory fungi of the Orbiliaceae based on evidence from rRNA-encoding DNA and multiprotein sequences. PNAS 104: 8379 - 8384. 